\title{
A Model to Build Performance for Batik Craftsmen in Competition Era
}

\author{
Luthfi Nurwandi \\ Industrial Engineering Department Universitas Widyatama \\ Bandung, Indonesia \\ e-mail: luthfi.nurwandi@widyatama.ac.id
}

\author{
Ishak Abdulhak, Endang Sumantri, Jajat S Ardiwinata \\ Pendidikan Luar Sekolah, Fakultas Ilmu Pendidikan \\ Universitas Pendidikan Indonesia Bandung, Indonesia
}

\begin{abstract}
The aim of this research is propose a model that can be accommodated for constructing performance in the level of design for adults. Performance for adults in the competition era is arena to build an advantage of design competency, especially on facing competition era for adult's society who works in the batik sector. Two main variables observed in this research, namely adult learning characteristics in competition era, and universal design characteristics that affect to raise the awareness of batik craftsmen for producing performance in batik design. Learning behavior characteristics for adult in competition era, that proposed in this research based on the condition of adults in facing competition era, which contains indicator namely: explorer, reflexive, self-actuating agent, and integrator. Learning behavior characteristics for adult, will be performing, if stimulated by universal design characteristic, as the main ware that must be mastered by adults who worked as a craftsmen at batik sector. According to this research the indicator universal design contain four indicators, namely: supportive, adaptable, accessibility, and safe. According to this research learning behavior characteristics and universal design characteristics, will be together affect to the adults performance in the competition area, because performance will be rising, if the adults has a knowledge and skill in batik design, and also stimulated by hearing voice of customer, that explain needs and wants of customer in global market. Quantitative method apply on this research with twenty five sample of craftsmen which placed at batik SMEs at Garut regency, and final result depict that the needs of learning design, must be stimulated by well known the characteristics of customer first, which learn in universal design characteristics, and finally learning characteristics together with universal design characteristics, will assure to accommodate the awareness the performance of adults in improving competency directly.
\end{abstract}

\section{Keywords_Design; Adult; Learning; Performance}

\section{INTRODUCTION}

In an era of competition, there is an aspect that is worthy of note specifically, characteristics to produce a products that pay attention to quality, cost, time, and service [70]-[71]-[72]. The fourth aspects are the characteristic performance to produce a product or service that should be shown by the individual or organization who will enter the global market in competition era.

Products or services are generally produced by the large industry, that is able to generate products and services on a large scale, and has a patent in a relatively large volume consumers, but in free-market competition, there is a peculiarity which consumers have different needs, than the product or service being marketed. The condition of the average failed to meet by large industry, so that consumers turn to industries that are able to meet the requirements their expected.

Small and medium enterprises (SMEs), particularly in Indonesia operated by a family and have employees who have the orientation to maintain life. As some of the weaknesses that became common features of SMEs in Indonesia, among others, in Refs. [1] - [2] are the quality of human resources (HR) is low (particularly formal education), including the ability to see business opportunities limited, work ethic and discipline is low, exploitative use of labor tends, in general, use of family members as workers' wages are not clear, the added value obtained is low, and the accumulation is not measurable, and government regulations are not feasible.

Notice the phenomenon that occurs in SMEs in Indonesia, important to note, the efforts to improve the performance of products and services in order to face the global market, especially for employees who produce products or services. This research will be presented a quantitative study to examine determinants that shape the performance of a product which contains the design aspects, namely batik craftsmen. In the era of global SME and batik makers must pay attention to aspects of the climate of competition [3], which is pay attention to quality in the form of design, as the spearhead of the resulting product [4]-[5], the designer must have the competence and qualifications, as a measure of performance that can be recognized by global markets [6]-[7], in the form of creating or designing a pattern motif. Another aspect is the motivation to create a design that has a value of achievement, which translate cultural values are evolving in the environment, in order to obtain a batik design with strong character [8]-[9]. To fulfill these conditions, the batik should explore the culture through a creative efforts, so as to create patterns and designs innovative batik motif, through a continuous learning activity [10].

The performance is intended in this study, is an effort to produce products or services performed by adults who started from the design activity. Performance is shown by the ability to work, then the adults working ability shown by the effort to learn continuously address the risks arising on the environment and the good life in the present and future, in the form of 
environmental compete, this is in line with the thinking [11] [12], to build resilience through self-reliance for work, by exploiting the potential of the knowledge and skills possessed are in line with studies [13], as well as having a vision that learning is an ongoing process, in an effort to improve the quality of life, it is in line with the thinking and study [14][15][12]. Notice the significance of the performance, this research performance of adults described as an effort to face the competitive environment in a way to explore the potential of knowledge and skills through continuous learning, in order to build self-reliance, either individually or in groups to produce the design.

Consider that adults have the ability to face the challenges of environmental change on their own, it is important to note that the performance of adults should be equipped with knowledge and skills, that distinguish one individual to another individual who referred to the competence [16]-[17]-[18]. Competency requirements, can be encouraged by the motivation in adults, because the performance required in the era of competition varies according to the development of science, which is resulting in the rapid changing global environment. Motivation is in adults, especially in the era of competition is to achieve a feat motif [19]-[20]-[21]. So that the individual is able to provide a distinctive color that characterize, some advantages.

\section{METHODS}

Based on the performance of batik craftsmen in SMEs, it can be concluded that the performance is an effort to improve living standards, through two things: getting competence, and the impetus to always have the motivation to excel. Design competence is to seek recognition through two activities make design batik and batik pattern, made through the learning process, while the achievement motivation can be raised by pledging to implement the batik craftsmen, universal design activities.

Aspects required to build the performance of batik craftsmen in the field of design, in the era of competition is competence, which characterize produced a draft. According to [14], establishing a community, is strongly influenced by the recognition of the work or the competence, so it is clear that the performance is the root of an effort to get an award on a community that emphasizes aspects of expertise and professionalism [13]-[15] on a job, as well as the motivation to always produce something unique and valuable [11]-[12]. This research will note two factors that will characterize the performance of batik is the awareness to have the competence [22]-[23]-[24]-[25]-[26], as well as awareness to have the motivation to excel [19]-[27]-[28]-[29]-[30].

In order to establish the performance of the design of the batik craftsmen, important to note the factor with respect to the face of the competitive environment, such as learning characteristics, the design characteristics and performance of adults in competitive era, as stated in [31]-[32]-[33]-[34] , Characteristics of adult learning in the era of competition, further characterize the efforts to establish the expertise or professionalism [35], as the hallmark of excellence, where adults minimize learning structured process, as well as avoiding the training, but it requires the recognition of the phenomenon, in which learning style adults have criteria as follows: explorer [36], reflexive [37], self-actualizing agent [38]-[39], and integrator [40]-[41].

On design aspects that affect the performance and learning of adults, in particular [42]-[43]-[44], stated that the design has affected the quality of life, in which one of the efforts to improve the quality of life of which is to increase knowledge as stated by [45]-[46]-[47], and skills [48]-[49]-[50]-[51], which can be obtained through a learning process, so it's understandable if design characteristics directly influenced the pattern of adults carry in the field of design learning process, in order to form the competence [35] which is capable of producing superior design. Design characteristics that affect the performance of batik craftsmen and learning process following has characteristics namely: supportive [9]-[44]-[52]-[53], Adaptable [9]-[54]-[55] [56], Accessible [9]-[57]-[58]-[59] [60], and safe [9]-[61]-[62] [63].

Quantitative methods apply on this research which involved two steps namely specify hypothesis, model research construction, execution with SMART PLS Ver 3.0, and analysis (result and discussion). The steps to get determinant factors that affect the performance of batik craftsmen, it will be explained through stages as follows:

\section{A. Step 1: Specify hypothesis.}

In this study the performance of batik craftsmen influenced by the design of learning activities, and the activities of design, so that there will be three hypotheses in order to obtain information regarding factors, determinants that affect the performance awakening resulted in the design, the batik craftsmen, namely:

- Hypothesis 1: Effect of batik craftsmen learning characteristics $(\mathrm{X} 1)$, to batik craftsmen performance $(\mathrm{Y})$ or $\mathrm{X} 1 \rightarrow \mathrm{Y}$.

$\mathrm{H}_{0} \quad$ : The construct of batik craftsmen learning characteristics (X1), does not contribute to significantly effect to batik craftsmen performance (Y) as in Refs. [39]- [40].

$\mathrm{H}_{1} \quad$ : The construct of batik craftsmen learning characteristics (X1), contribute to significantly effect to batik craftsmen performance (Y) as in Refs. [35]- [36] [37]-[41].

- Hypothesis 2: The influence of batik craftsmen design characteristics (X2), to batik craftsmen learning characteristics $(\mathrm{X} 1)$ or $\mathrm{X} 2 \rightarrow \mathrm{X} 1$.

$\mathrm{H}_{0} \quad$ : The construct of batik craftsmen design characteristics (X2), does not contribute to significantly effect to batik craftsmen learning characteristics (X1) as in Refs. [47]- [50]-[64].

$\mathrm{H}_{1} \quad$ : The construct of batik craftsmen design characteristics (X2), contribute to significantly effect to batik craftsmen learning characteristics (X1) as in Refs. 
[45]- [46]-[48]-[49]-[51].

- Hypothesis 3: The influence of batik craftsmen design characteristics (X2), to batik craftsmen performance $(\mathrm{Y})$ or $\mathrm{X} 2 \rightarrow \mathrm{Y}$

$\mathrm{H}_{0}$ : The construct of batik craftsmen design characteristics (X2), does not contribute to significantly effect to batik craftsmen performance (Y) as in Refs. [65].

$\mathrm{H}_{1} \quad$ : The construct of batik craftsmen design characteristics (X2), contribute to significantly effect to batik craftsmen performance (Y) as in Refs. [66]- [67] [68].

\section{B. Step 2: Model reasearch construction.}

In order to facilitate of testing of the model research construction, the simplification of symbols use, along with related research instruments, as described in Table I, while the variable name changed to construct, which is directed by the terms used in SMARTPLS Version 3.0.

TABLE I. CONVERSION SYMBOL.

\begin{tabular}{|l|l|l|l|}
\hline Construct & \multicolumn{1}{|c|}{$\begin{array}{c}\text { Measurement } \\
\text { Factors }\end{array}$} & $\begin{array}{c}\text { Conversion } \\
\text { Symbols }\end{array}$ & \multicolumn{1}{|c|}{$\begin{array}{c}\text { Research } \\
\text { Instrument }\end{array}$} \\
\hline X1 & Explorer & A & A1 \& A2 \\
& Reflexive & B & B1 \& B2 \\
& Self Actualizing & C & D1 \&2 \\
& Agent & D & D1 \& D2 \\
& Integrator & E & E1 \& E2 \\
\hline X2 & Supportive & F & F1, F2, \& F3 G1 \& \\
& Adaptable & G & G2 \\
& Accessible Safe & H & H1 \& H2 \\
\hline Y & Competency & I J & I1, I2,.., \& I14 J1, \\
& Motivation & & J2, J3, \& J3 \\
\hline
\end{tabular}

The data used to execute in SMARTPLS Version 3 shown on Table 2

TABLE II. DATA RESULTS FROM RESPONDENT

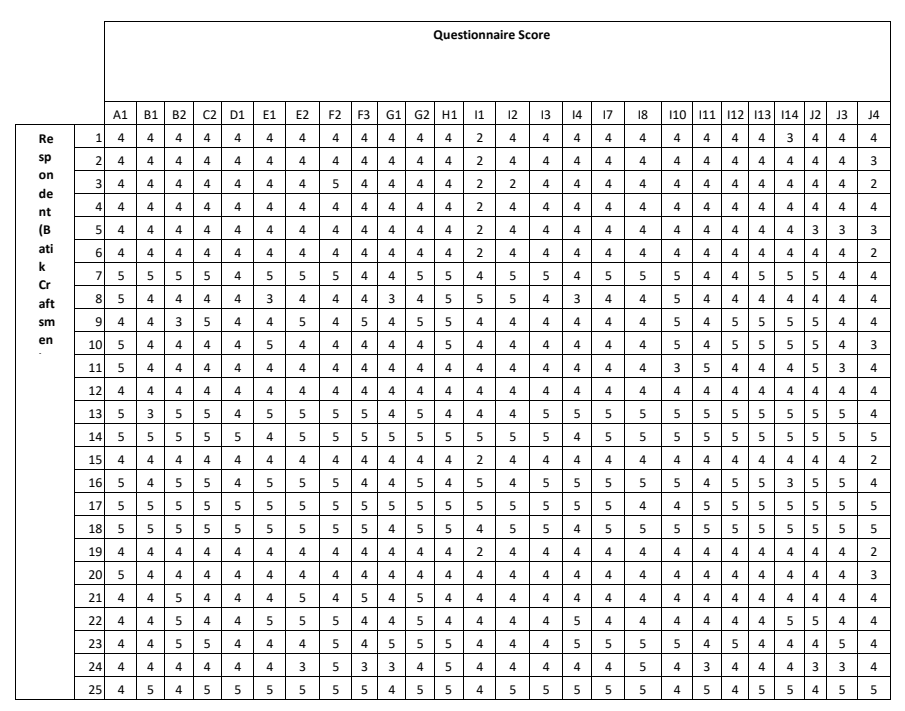

C. Step 3: this section was examined by using SMARTPLS Version 3, the results were discussed at the result and discussion part.

D. Step 4: this section will be determined what factors affect the performance of batik artisans, who served at the conclusion.

\section{RESULT AND DISCUSSION}

SMARTPLS VERSION 3.0, used to test the model through several stages, as described below:

\section{A. Step 1: Loading factors test.}

In this step several research instruments do not have a value of 0.7 or more loading is between greater than 0.5 and less than 0.7 [69], while the instrument of each construct, which can still be used for further testing, are presented in Table 3.

TABLE III. RESULT OF LOADING FACTORS.

\begin{tabular}{|l|l|}
\hline \multicolumn{1}{|c|}{ Construct } & \multicolumn{1}{|c|}{ Research Instrument } \\
\hline $\mathrm{X} 1$ & $\mathrm{~A} 1, \mathrm{~B} 1, \mathrm{~B} 2, \mathrm{C} 2$, \& D1 \\
$\mathrm{X} 2$ & $\mathrm{E} 1, \mathrm{E} 2, \mathrm{~F} 2, \mathrm{~F} 3, \mathrm{G} 1, \mathrm{G} 2$, \& H1 \\
$\mathrm{Y}$ & $\mathrm{I} 1, \mathrm{I} 2, \mathrm{I} 3, \mathrm{I} 4, \mathrm{I} 7, \mathrm{I} 13, \mathrm{I} 14, \mathrm{~J} 2, \mathrm{~J} 3$, \& J4 \\
\hline
\end{tabular}

B. Step 2: Colinearity test.

In this step collinearity of the model tested, by reviewing the relationship between the instruments. Relations between the instruments is not allowed, this condition is shown when an instrument has a value below 5 [69]. Result of the test of the instruments are presented in Table 3 , and it was found that the instrument E2, G2, I2, I7, and J3 has a value of collinearity above 5, so it will be coupled with an instrument that is closest, and still at the same construct, so that the result of the merger presented in Table 4.

TABLE IV. RESUlt ACCUMUlated InSTRUMENT SCORE.

\begin{tabular}{|c|c|}
\hline Construct & Research Instrument \\
\hline $\mathrm{X} 1$ & $\mathrm{~A} 1, \mathrm{~B} 1, \mathrm{~B} 2, \mathrm{C} 2$, \& D1 \\
$\mathrm{X} 2$ & $\mathrm{E} 1 \mathrm{E} 2, \mathrm{~F} 2, \mathrm{~F} 3, \mathrm{G} 1 \mathrm{G} 2$, \& H1 \\
$\mathrm{Y}$ & $\mathrm{I} 1, \mathrm{I} 2 \mathrm{I} 3, \mathrm{I} 4, \mathrm{I} 7 \mathrm{I} 13, \mathrm{I} 14, \mathrm{~J} 2 \mathrm{~J} 3$, \& J4 \\
\hline
\end{tabular}

\section{Step 3: T Statistics test.}

In general, statistical $\mathrm{T}$ test carried out on both sides, if the value of the test statistic $\mathrm{T}\left(\mathrm{T}_{\mathrm{h}}\right)$ is greater than $\mathrm{T}$ table $\left(\mathrm{T}_{\mathrm{r}}\right)$ [69] then the hypothesis is accepted. The results of testing on the construction of the final model with the value of the test statistic $\mathrm{T}$ both instruments and constructs. The statistical $\mathrm{T}$ test results from the instrument to each construct is greater than 1.96, it indicates that each instrument has a significant influence on each construct. And determined that all the factors influence to the construct will be able used for ongoing test.

In construct $\mathrm{X} 1$, it appears that the process of learning for batik craftsmen dominated by the aspect of self-actualizing agent $(\mathrm{C})$, so that the learning process would be nice if craftsmen are given the freedom to do the excavation activity designs tailored to the potential of the knowledge and skills already possessed [39], and have a tendency to learn 
independently rather than in groups (C2) which is in line with research [38].

In constructs $\mathrm{X} 2$, dominated by aspects of supportive $(\mathrm{E})$, so batik will be easier to shape the behavior of batik design, if given the freedom to conduct excavations independently, starting from the notice function batik design [44], which is derived from the needs of consumers, hereinafter set forth in the draft, taking into account the appearance of batik cloth [52]-[53].

In construct $\mathrm{Y}$, batik prefers to have the expertise of the organization placing motifs or ornaments on batik (I7) as proposed by [22]-[23], and the like on the efforts to store and organize tools and results of the work (I13) as described by [23], at a designated place as an integral combined expertise or referred to as managerial ability to control the outcome of work [24]-[25].

With regard to the results of $\mathrm{T}$ statistics test, the effect of inter-constructs in general hypothesis is unacceptable, because the value of the test statistic $\mathrm{T}$ is greater than 1.96, as shown in Table 5.

TABLE V. RESUlt OF T STATISTICS FOR CONSTRUCT.

\begin{tabular}{|l|l|l|l|}
\hline \multicolumn{1}{|c|}{ Hypothesis } & \multicolumn{1}{|c|}{$\mathbf{T}_{\mathbf{h}}$} & \multicolumn{1}{|c|}{$\mathbf{T}_{\mathbf{r}}$} & \multicolumn{1}{c|}{ Annotation } \\
\hline $\mathrm{X} 1 \rightarrow \mathrm{Y}$ & 2.132 & 1.96 & H1 Accepted \\
$\mathrm{X} 2 \rightarrow \mathrm{X} 1$ & 22.028 & 1.96 & H1 Accepted \\
$\mathrm{X} 2 \rightarrow \mathrm{Y}$ & 4.141 & 1.96 & H1 Accepted \\
\hline
\end{tabular}

In the first hypothesis looks constructs $\mathrm{X} 1$ significant influence to construct $\mathrm{Y}$, this phenomenon shows that the batik craftsmen require knowledge and additional skills that are focused to achieve competence [34] draft and batik patterns, that can be accepted by the global market in the era of competition [40], in addition to the competence of batik is also important to establish the behavior produces batik designs that have unique characteristics [36], so as to build a sustainable batik designing performance individually and collectively [40].

In the second hypothesis, it can be a phenomenon that batik requires learning object, in this case is shaping the behavior of designs that address the needs of consumers [47], then poured in a learning process that ensures fosters design behavior on an ongoing basis [44], as well as to encourage the emergence a unique character that is characteristic of batik craftsmen individual or in groups [48]-[50].

In the third hypothesis, give a summary that the batik craftsmen produce a performance that can be accepted by the global market, should have a design behavior, where the batik craftsmen must consider a market environment where batik design is acceptable [65], and able compete with similar products. Another phenomenon that draws on third hypothesis is batik informally could do batik designs that can be accepted by the global market [41], without going through a learning process to obtain the expertise of [66], but the batik craftsmen must be industrious and diligent practice to grasp and understand pattern forming design behavior that can be accepted by the global market [42].

\section{CONCLUSION.}

Performance batik craftsmen, to produce batik designs that can be accepted by the global market, influenced by the efforts of batik artisans to improve their knowledge and skills perform design activities, which in this study was influenced by selfactualizing agent, which makes batik as a center for exploring sources of learning, as well as being an actor to spread the knowledge and skills of the individuals or groups who have a need to learn batik design.

Learning process for batik craftsmen is influenced by the behavior of the design activity, which is strongly influenced by supportive factors, which shape the behavior of batik designs with batik by concern with function and appearance to be made.

The learning process and the behavior of the design together perform, the expertise and achievement motivation for batik, which is a component for forming performance to produce batik design with unique characters and will be accepted by the global market.

\section{REFERENCES}

[1] Tambunan, T.T.H. 2002. Usaha Kecil dan Menengah di Indonesia: Beberapa Isu Penting. Jakarta: Salemba Empat.

[2] Tambunan, T.T.H. 2009. SMEs in Asian Developing Countries. New York: Palgrave Macmillan.

[3] Crawford, M., \& Anthony, D. 2008. New Product Management. Singapore: McGrawHill.

[4] Cross, N. 2000. Engineering Design Methods: Strategies for Products Design $3^{\text {rd }}$ Edition. Chichester: John Wiley \& Sons. LTD.

[5] Dealtry, R. 2009. The Design and Management of an Organization's Lifelong Learning Curriculum. Journal of Workplace Learning. 21(2), hlm. 156-165.

[6] Austin, S. 2001. Mapping The Conceptual Design Activity of

[7] Interdiciplinary Teams. Design Studies. 22(3), hlm. 211- 231.

[8] Cardella, M.E., Cynthia, J.A., \& Robin, S.A. 2006. Mapping Between Design Activities and External Representations for Engineering Student Designers. Design Studies. 27(1), hlm. 5-24.

[9] Florida, R., \& Irene, T. 2004. Europe In The Creative Age. Europe: DEMOS.

[10] Null, R. 2014. Universal Design: Principles and Models. Boca Raton: CRC Press Taylor \& Francis Group.

[11] Burns, K. 2009. Exploring Design capability in Terms of Absorptive Capacity and Tipping Points. $8^{\text {th }}$ European Academy of Design Conference. Scotland: The Robert Gordon University, Aberden.

[12] Brookfield, S.D. 2005. The Power of Critical Theory for Adult Learn and Teaching. New York: Open University Press.

[13] Dunlap, J.C. 2005. Changes in Students' Use of Lifelong Learning Skills During a Problem-Based Learning Project. Performance Improvement Quarterly. Vol. 18(1), hlm. 5-33.

[14] Dunlap, J.C., \& Scott, G. 2003. Preparing Students for Lifelong Learning: A Review of Instructional Features and Teaching Methodologies. Performance Improvement Quarterly. Vol. 16(2), hlm. 6-25.

[15] Grow, G.O. 1991. Teaching Learners to be Self-Directed. Adult Education Quarterly. Vol. 41(3), hlm. 125-149.

[16] Hake, B.J. 1999. Lifelong Learning in Late Modernity: The cHallenges to Society, Organizations, and Individuals. Adult Education Quarterly. Vol. 49(2), hlm. 79-90.

[17] Dubois, D.D., William, J.R., Deborah, J.K.S., \& Linda, K.K. 2004.

[18] Human Resource Management. Mountain View: Davies-Black 
[19] Publishing.

[20] Dana, R.H., \& James, R.A. 2008. Cultural Competency Training in A Global Society. New York: Springer.

[21] Kessler, R. 2008. Competency-Based Performance Reviews: Hot to Perform Employee Evaluations the Fortune 500 Way. Franklin Lakes: Career Press.

[22] McClelland, D. 1987. Human Motivation. United States of America: Cambridge University Press.

[23] Wlodkwoski, R.J. 2008. Adult Motivation to Learn: A Comprehensive Guide for Teaching All Adult. San Francisco: Josey-Bass by John Wiley \& Sons.

[24] Erez, M., Uwe, K., \& Henk, T. 2008. Work Motivation in The Context of

[25] A Globalizing Economy. Mahwah: Lawrence Erlbaum Associates,

[26] Publishers.

[27] Dreyfus, C.R. 2008. Identifying Competencies that predict effectiveness of R\&D Managers. Journal of Management Development. Vol. 27(1), hlm. 76-91.

[28] Boyatzis, R.E., \& Franco, R. 2009. Emotional, Social, and Cognitive Intelligence Competencies Distinguishing Effective Italian Managers and Leaders in A Private Company and Cooperatives. Journal of Management Development. Vol. 28(9), hlm. 821-838.

[29] Camuffo, A., Fabrizio, G., \& Paolo, G. 2012. Competencies Matter: Modeling Effective Entrepreneurship in Northeast of Italy Small Firms. Cross Cultural Management. Vol. 19(1), hlm. 48-66.

[30] Ryan, G., Lyle, M.S., \& Urs, B. 2012. Development and Validation of A Customized Competency-Based Questionnaire: Linking Social, Emotional, and Cognitive Competencies to Business Unit Profitability. Cross Cultural Management. Vol. 19(1), hlm. 90-103.

[31] Ahl, H. (2006). Motivation in Adult Education: A Problem Solver or A Euphemism for Direction and Control?. International Journal of Lifelong Education. Vol. 25(4), hlm. 385-405.

[32] Green, T.M., \& Chandrika, M.K. 2006. Factors That Affect Motivation Among Adult Learners. Journal of College Teaching \& Learning. Vol. 3(4), hlm. 65-74.

[33] Gorges, J., \& Christian, K. 2012. Adults' Learning Motivation: Expectancy of Success, Value, and The Role of Affective Memories. Learning and Individual Differences. Vol. 22, hlm. 610-617.

[34] Hubackova, S., \& Ilona Semradova. 2014. Research Study on Motivation in Adult Education. Procedia-Social and behavioral Sciences. Vol. 159, hlm. 396-400.

[35] Chappell, C., Carl, R., Nicky, S., Mark, T., \& Lyn, Y. 2003. Reconstructing The Lifelong Learner: Pedagogy and Identity in Individual, Organisational, and Sosial Change. London: RoutledgeFalmer.

[36] Jarvis, P. 2004. Adult Education and Lifelong Learning $3^{\text {rd }}$ Edition. London: RoutledgeFalmer.

[37] Tennant, M., 2006. Psychology and Adult Learning. London: Routledge Taylor \& Francis Group.

[38] Knowles, M.S., Elwood, F.H III., \& Richard, A.S. 2005. The Adult Learner $6^{\text {th }}$ Edition. Amsterdam: Elsevier.

[39] UNESCO. 2009. Global Report on Adult Learning and Education. Hamburg: UNESCO Institute for Lifelong Learning.

[40] Anonuevo, C.M., Toshio, O., \& Werner, M. 2001. Revisiting Lifelong Learning for $21^{\text {th }}$ Century. Hamburg: The UNESCO Institute for Education.

[41] De Goni, J.I.M.dM. 2006. What is Adult Education? UNESCO ANSWER. San Sebastian: UNESCO.

[42] Hefler, G., \& Jorg, M. 2010. Formal adult Learning and Workingin Europe: a New Typology of Participation Patterns. Journal of Workplace Learningi. Vol. 22(1/2), hlm. 79-93.

[43] Aguiar, M., \& Ana, M.S. 2012. New Skill in Adult Education and Training: The Field of Mediation in Portugal and France. Procedia Social and Behavioral Sciences. Vol. (69), hlm. 890-898.

[44] Longenecker, C., \& Rob, A.2013. The Eight Imperatives of Effective Adult Learning: designing, Implementing, and Assessing Experiences in The Modern work Place. Human resource Management Internasional Digest. Vol 21(7), hlm. 30-33.
[45] Lester, S. 2014. A Vocational Qualifications System Fit for Adults? Revisiting Some Ideas from The University for Industry. Higher Education, Skills, and Work-Based Learning. Vol. 5(2), hlm. 102-116.

[46] Fisk, A.D., Wendy, A.R., Neil, C., Sara, J.C., \& Joseph, S. 2005. Designing for Older Adults. London: CRC Press.

[47] Vink, P. 2005. Comfort and Design: Principles and Good Practice. Boca Raton: CRC Press.

[48] Pak, R., \& Anne, M.2011. Designing Display for Older Adults. London: CRC Press.

[49] Matheson, D., \& Catherine, M. 1996. Lifelong Learning and Lifelong Education: a Critique. Research in Post-Compulsory Education. Vol. 1(2), hlm. 219-236.

[50] Rodgers, A. 2005. Non-Formal Education: Flexible Schooling or Parcipatory Education? The University of Hongkong: Kluwer Academic Publisher.

[51] Rosanna, B. 2012. From Lifelong Learning. Discussion of Some effects of Today's Neoliberal Policies. European Journal for Research on The Education and Learning of Adults. Vol. 3(2), hlm. 119=134.

[52] Lorriman, J. 1995. Lifelong Learning in Japan. Journal of European Industrial Training. Vol. 19(2), hlm. 8-14.

[53] Ahlgren, L., \& Laura, C.E. 2011. Lifelong Learning Through SMEs: Exploring Workplace Learning in The UK. Journal of Workplace Learning. Vol. 23(5), hlm. 331-348.

[54] Sung, M. 2015. A Study of Adults' Perception and Needs for Smart Learning. Procedia-Social ad behavioral Sciences. Vol. 191, hlm. 115120.

[55] Marzano, G., Velta, L., \& Svetana, U. 2015. Involving Adult Educators in Quality Assessment Process. 2015. Procedia-Social ad behavioral Sciences. Vol. 197, hlm. 2174-2181.

[56] Lockton, D., David, J.H., Rebecca, C., Neville, A.S., \& Paul, J. 2013. Exploring Problem-Framing Through Behavioural Heuristics.

[57] International Journal of Design. Vol. 7(1), hlm. 37-53.

[58] Valencia, A., Ruth, M., Jan, P.L.S., \& Hendrrick, N.J.S. 2015. The design of Smart Product-Service Systems (PSSs) An Exploration of Design Characteristics. International Journal of Design. Vol. 9(1), hlm. 13-28.

[59] Lindgren, A., Fang, C., Patrick, W.J., \& Haixin, Z. 2008. Requirements for Design of Advanced Driver Assistance Systems- The Differences Between Swedish and Chinese Drivers. International Journal of Design. Vol. 2(2), hlm. 41-54.

[60] Kelly, J., \& Stephen, A.G.W. 2014. Designing to Bring The Field to The Showroom Through Open-Ended Provocation. International Journal of Design. Vol. 8(2), hlm. 71-85.

[61] Koskinen, L., \& Peter, G.K. 2015. Design Accountability: When Design Research Entangles Theory and Practice. International Journal of Design. Vol. 9(1), hlm. 121-127.

[62] Schifferstein, H.N., \& Elly. P.H.Z.P. 2008. Consumer- Product Attachment: Measurement and Design Implications. International Journal of Design. Vol. 2(3), hlm. 1-13.

[63] Denef, S., Reinhard, O., \& David, V.K. 2011. Designing for Social Configurations: Pattern Languages to Inform The Design of Ubiquitous Computing. International Journal of Design. Vol. 5(3), hlm. 49-65.

[64] Forslund, K., MariAnne, K., \& Rikard, S. 2013. Impacts of Geometrical Manufacturing Quality on The Visual Product Experience. International Journal of Design. Vol. 7(1), hlm. 69-84.

[65] Te Vaarwerk, M., Thomas, J.L.V.R., \& Vanessa, S.O. 2015. Under Cover and Close at Hand: Embodied Metaphor in Packaging Design.

[66] International Journal of Design. Vol. 9(1), hlm. 29-37.

[67] Jerrard, R., Nick, B., \& Adele, R. 2008. Design, Risk, and New Product Development in Five Small Creative Companies. International Journal of Design. Vol. 2(1), hlm. 21-30.

[68] Charness, N., George, D., \& Elizabeth, K. Designing Telehealth for an Aging Population: A Human Factors Perspective. London; CRC Press.

[69] Kanstrup, A.M. 2014. Design Concepts for Digital Diabetes Practice: Design to Explore, Share, and Camouflage Chronic Illness. International Journal of Design. Vol. 8(3), hlm. 49-60. 
[70] Aspin, D., \& Judith, D.C. 2007. Philosophical Perspectives on Lifelong Learning. Dordrecht: Springer.

[71] Rubenson, K. 2006. The Nordic Model of Lifelong Learning. Compare. Vol. 36(3), hlm. 327-341.

[72] World Bank. 2003. Lifelong Learning in The Global Knowledge Economy: Challenges for Developing Countries. Washington D.C: The international Bank for Reconstruction and Development/ The World Bank.

[73] Issaksson, R., Rickard, G., Mikael, J., Christer, K., \& Jorg, P. 2015. Sustaining Sweden's Competitive Position: Lean Lifelong Learning. Measuring Business Excellence. Vol. 19(1), hlm. -.

[74] Vink, P. 2005. Comfort and Design: Principles and Good Practice. Boca Raton: CRC Press.

[75] Hair, JR, J. F. G. Tomas, M. H, Christian, M. R, \& Marko, S. 2014. A Primer on Partial Least Squares Structural Equation Modeling (PLSSEM).

[76] Takey, S.M., Marly, M.DC. 2014. Competency Mapping in Project Management: An Action Research Study in An Engineering Company. International Journal of Project Management. Vol. xx, hlm. xx-xx.

[77] Manalo, R. G., \& Manalo, M. V. (2010). Quality, Cost, Delivery Performance Indicators and Activity- Based Costing. Institute of Electrical and Electronics Engineers (IEEE) International Conference on Management of Innovation and Technology (ICMIT). hlm 869- 874.

[78] Sharma, S. (2013). Vendor Development Process in Automobile Industry in India: A Comparative Study. International Journal of Advance Research in Computer Science and Management Studies. 1(6). hlm. 118- 124.

[79] Kumar Das, A., \& Anasua, M.D. Role of Lifelong Learning in Emerging Knowledge Economy in India. Diakses ; http: //eprints.rclis.org/ 13031/ 1/ Lifelonglearning_Anup_Anasua.pdf.2015. 